\title{
Klassiõpetajate keele- ja suhtluseeskuju hindamine emakeeletunnis struktureeritud vaatluse teel
}

\author{
Krista Uibu ${ }^{\text {al }}$, Marika Padrik ${ }^{a}$, Silvi Tenjes ${ }^{b}$ \\ a Tartu Ülikooli haridusteaduste instituut \\ ${ }^{b}$ Tartu Ülikooli maailma keelte ja kultuuride kolledž
}

\begin{abstract}
Annotatsioon
Õpetaja keele- ja suhtluseeskuju mõjutab oluliselt õppeprotsessi kvaliteeti. See realiseerub harjumuspärase tunnisuhtlusstiilina, mis hõlmab nii mitteverbaalse kui ka verbaalse suhtluse komponente: õpetaja ja õpilaste tegevuste kommenteerimist, õpilaste vastuste kordamist ja laiendamist, küsimuste valikut ning keelekasutuse raskusastme varieerimist. Uurimuse eesmärk on hinnata struktureeritud vaatluse teel klassiõpetajate $(N=46)$ suhtlusstiile ja nende seoseid õpilaste ( $N=611)$ emakeeleoskustega 3. klassis. Rühma- ja indiviidikesksete analüüside ning multimodaalse videoanalüüsi põhjal ilmneb neli suhtlusprofiili, mis eristuvad verbaalse ja mitteverbaalse suhtluse komponentide kasutuse poolest. Kõige vähem kasutavad õpetajad emakeeletunnis enda ja õpilaste tegevuste kommenteerimist ning kõige rohkem õpilaste vastuste kordamist ja täiendamist. Uurimistulemustest selgub, et õpetajatel, kelle suhtlusstiil sai kõrge hinnangu, on oodatust rohkem emakeeletestis kehvema tulemuse saavutanud õpilasi.
\end{abstract}

Võtmesõnad: tunnisuhtlusstiil, suhtlusprofiil, klassiõpetaja, struktureeritud vaatlus

\section{Sissejuhatus}

Õpetaja keelekasutust õppeprotsessis on uuritud aktiivselt alates 1970. aastatest, mil Flanders (1970) sõnastas nn kahe kolmandiku seaduse: tunnis pühendatakse suhtlusele tavaliselt $2 / 3$ ajast, millest õpetaja räägib omakorda 2/3 (viidatud Mercer \& Dawes, 2014 järgi). Lyle’i (2008) sõnul pole kahtlust, et õpetaja kujundatud klassiruumi diskursusel on suur mõju

1 Haridusteaduste instituut, Tartu Ülikool, Salme 1a, 50103 Tartu; krista.uibu@ut.ee 
õpilaste koolikogemusele. Ühelt poolt on õpetaja asjatundja, kes suunab vestlust (Garcia, Pearson, Taylor, Bauer, \& Stahl, 2011), teiselt poolt aga eeskuju: õpetaja kognitiivselt nõudlik keelekasutus on seotud laste oskusega kasutada samasugust keelt. Samas ei avalda keeleliselt vahendatud ühine õppimine mõju ainult laste keeleoskusele, vaid mõjutab ka nende õpioskusi (sh eneseregulatsiooni ja metakognitsiooni) ning kognitiivset arengut (Mercer, 2013; Pianta, La Paro, \& Hamre, 2008). Viimastel kümnenditel on uurijaid rohkem köitnud õpetaja-õpilase verbaalse suhtluskoostöö ehk interaktsiooni kvaliteet, mis on positiivselt seotud kõne mõistmise ja loomise oskuste arenguga koolieelses eas ning emakeele õpitulemustega koolis (Burchinal, Peisner-Feinberg, Pianta, \& Howes, 2002; Damhuis \& Blauw, 2008; Garcia et al., 2011; Howes et al., 2008; Mashburn et al., 2008; Reznitskaya et al., 2001). Õppeprotsessi multimodaalse ehk mitmeviisilise olemuse tõttu tuleks pöörata tähelepanu ka verbaalset suhtlust toetavatele mitteverbaalsetele suhtlusviisidele ehk kommunikatiivsetele kehaliigutustele: žestidele, mitteverbaalsetele sümbolitele, ruumilistele tingimustele ja prosoodiale (Mercer, 2013). Üksmeelel ollakse selles, et õpetajad peaksid analüüsima oma keelekasutust ja suhtlust klassis ning tundma selle rolli õpilaste arengus. Samas on õpetajate suhtlus klassis pigem ebateadlik ning aja jooksul kujuneb neil välja tunnis kasutatav harjumuslik stiil. Õpetaja-õpilaste suhtluskoostöö kvaliteedile, sh õpetaja tunnisuhtlusstiilile, pööratakse aga põhjendamatult vähe tähelepanu (Lyle, 2008; Mercer, 2013; Mercer \& Dawes, 2014; Pentimonti \& Justice, 2009; Thompson, 2008).

Ka Eestis on uuritud oppetaja suhtlemisoskusi (Krips, 2011, 2013) ja mitteverbaalset suhtlust (Ingerpuu-Rümmel, 2012; Mihkels, 2013), kuid puuduvad uurimused sellest, kuidas õpetaja kujundab oma keelekasutuse ja mitteverbaalse suhtlusega klassiruumi diskursust ning kuidas mõjutab see õpilaste arengut. Selles artiklis vaadeldakse, millist eeskuju pakuvad klassiõpetajad õpilastele oma keelekasutuse ja suhtlemisega tunniolukorras. Uurimuse eesmärk on analüüsida õpetajate verbaalse ja mitteverbaalse suhtluse komponente emakeeletunnis ning suhtlusstiilide seoseid õpilaste emakeeleoskustega 3. klassis.

\section{Õpetaja suhtlusfunktsioonid ja -võimalused tunnis}

Sotsiaalkonstruktivistliku õpiteooria kohaselt on oluline kasutada õppeprotsessis dialoogilist õpetust (Lyle, 2008). See nõuab nii rääkimist kui ka kuulamist ning võimaldab õpilastel olla aktiivne ja õpitavast paremini aru saada. Võgotski (2014) järgi arenevad kõrgemad psüühilised protsessid sotsiaalses vastastikmõjus ning keel ei ole pelgalt mõtete väljendamise vahend, 
vaid mõtted kujunevad ja täpsustuvad kõnes. Mercer (2013), inspireerituna Võgotskist, teeb üldistuse: kõnet ei kasutata ainult informatsiooni vahetamiseks, vaid see on sotsiaalse arutlemise ja mõtlemise viis. Seega on kõnel peale kommunikatiivse funktsiooni ka kognitiivne ehk tunnetustegevust suunav ja vahendav roll.

Õpetajal on võimalik toetada õppeprotsessis õpilase kommunikatiivset ja kognitiivset tegevust kolmel viisil: 1) kujundada arutelude kaudu uusi mõisteid ja mõtlemist, lähtudes õpilase varasemate teadmiste tasemest; 2) tagasisidestada õpilaste vastuseid; 3 ) arendada iseenda keelekasutuse kaudu õpilaste keelekasutust (Pianta \& Hamre, 2009; Salminen, 2014). Kuna mõistete kujundamine ja tagasiside andmine realiseeruvad keele abil, on eelnimetatud kolm aspekti omavahel põimunud, teenides sama eesmärki - võimaldada arusaamisega õppimist (Pianta \& Hamre, 2009). Selleks sobivad erinevad tehnikad, nt kokkuvõtte tegemine ja õpitust ülevaate andmine, täpsustavate küsimuste esitamine varem õpitu meenutamiseks ja seoste loomiseks ning avatud küsimuste sage kasutamine eesmärgiga suunata õpilast mõtlema (Nystrand, Wu, Gamoran, Zeiser, \& Long, 2003). Tähtsal kohal on ka õpilaste vastuste kordamine ja laiendamine oma märkuste ja näidetega ning vastuste ümbersõnastamine, et muuta laused lastele arusaadavamaks ja keeleliselt täiuslikumaks. Samas leiavad Margutti ja Drew (2014) oma uurimuses, et klassiõpetajad kasutavad õpilaste vastuste osalist või täielikku kordamist peamise positiivse tagasiside andmise viisina, mitte niivõrd laste mõttetegevuse suunamiseks.

Üks olulisimaid esimeses kooliastmes kujundatavaid õpioskusi on eneseregulatsioonioskus kui tõhusa õppimise määraja (Mercer, 2013). Õpilaste oskused oma tegevust suunata ja planeerida ning mõtlemist teadvustada arenevad õpetaja juhendamisel õpidialoogis (vt Wertsch, 1979). Selleks, et õpilane näeks ja saaks aru, kuidas õpetaja kui asjatundja mõtleb ja miks ta midagi teeb, peaks õpetaja kommenteerima enda tegevust, sh mõttetegevust, valjusti (nt Ma püüan lugeda nii, et teil on hea kuulata. Seega ma loen aeglaselt, selgelt, teen pause ja rõhutan olulisi sõnu). Sama oluline on see, et õpetaja kommenteeriks õpilaste tegevust või suunaks neid endid seda tegema (Karlep, 2005). Sellega annab õpetaja tagasisidet õpilase tegevuse, sh mõttetegevuse kohta ja suunab seda (nt Sa lugesid oma lause veel kord läbi, nii nagu kirjutasid, ja leidsid vea). Selgitusi eeldavad küsimused (Kuidas? Miks?), hinnangute andmine teiste ja enda tegevusele, aga ka oma tegevust kirjeldama ja põhjendama suunavad küsimused (Räägi, kuidas sa seda teed/tegid? Mida tegid selleks, et ...?) on kõne reguleeriva funktsiooni kujunemise teenistuses. 
Lyle'i (2008) hinnangul ei stimuleeri ükski käsitletud tehnikatest otseselt dialoogi, kuid õpilaste vastuste kordamine, ümbersõnastamine ja laiendamine annavad ópilasele tagasisidet, soodustades psühholoogilise kontakti püsimist ja realiseerumist ópidialoogis (vt ka Krips, 2011). Niisamuti soodustavad seda prosoodia (intonatsioon, rõhud, pausid ja tähenduslikud häälitsused $o h$, ssh jms) ning erinevad mitteverbaalsed suhtlusviisid, nt žestid, näoilmed, kehahoiak, pilgu suund (Allwood \& Ahlsén, 2012) ning suuga tehtavad ja nähtavad liigutused ehk viseemid, nt naeratused (Poggi, 2002). Õpetajaid uurides on leitud, et nende suhtlemine on väga informatiivne (Merola \& Poggi, 2003), sest õpetajal on õppeprotsessis erinevad suhtluskavatsused: ta esitab küsimusi, annab korraldusi ja nõu, kinnitab vastuseid, kiidab või laidab õpilasi. See soodustab kasutama tavapärase suhtlusolukorraga võrreldes rohkem kommunikatiivseid käeliigutusi (Bavelas, Chovil, Lawrie, \& Wade, 1992; McNeill, 1992).

\section{Õpetaja verbaalse suhtluse kvaliteedi seos õpilaste emakeeleoskustega}

Eesti põhikooli esimeses kooliastmes keskendutakse peale õpilaste keeleliste osaoskuste lõimitud arendamise ka nende õpi- ja suhtlemisoskuste kujundamisele ning tegevuse mõtestamisele ja eesmärgistamisele (Põhikooli riiklik õppekava, 2010). Võgotski (2014) järgi on emakeele õppimise eesmärk keelekasutuse teadvustamine, mis võimaldab edaspidi oma kõnetoiminguid tahtlikult ja teadlikult reguleerida. Õpetaja suunamisel muutuvad õpilaste ebateadlikult kontrollitav ehk keelevaistule toetuv kõne ja suhtlus teadlikult kontrollitavaks (vt ka Karlep, 2005). Oma küsimuste ja kommentaaridega juhib õpetaja õpilaste tähelepanu keelekasutusreeglitele ja õigekirjajuhistele. Õpetaja oskus valida küsimusi, teadvustades nende funktsioone, on oluline suhtluskoostöö kvaliteedi näitaja (Karlep, 2005; Mercer, 2013; Mercer \& Dawes, 2014).

Õpetaja verbaalse suhtluse mõju koolieelses eas laste keelelistele osaoskustele on uuritud palju. On leitud, et mõtlemist suunav ja arutlemist soodustav dialoog, õppimist ja keelekasutust mudeldava tagasiside andmine ning lähimas arenguvallas toimuv verbaalne suhtluskoostöö lastega seostuvad nii kõne mõistmise kui ka loomise oskuste arenguga (Damhuis \& Blauw, 2008). Oluline roll on õpetaja keelekasutuse raskusastmel (vt Gosse, McGinty, Mashburn, Hoffman, \& Pianta, 2014; Mashburn et al., 2008; Salminen, 2014). Lapsed, kelle õpetaja kasutab neile jõukohast lauseehitust ja sõnavara ning tagasisidestab laste vastuseid ja suhtlusalgatusi, loovad kõrgema taseme mikrostruktuuriga jutustusi (Gosse et al., 2014). Uurinud lasteaiaõpetajate kõne lauseehituse mõju laste süntaktiliste 
oskuste arengule õppeaasta vältel, leidsid Huttenlocher jt (2002), et nendes rühmades, kus kõne mõistmine arenes märgatavalt kiiremini, kasutasid õpetajad keerukamaid, kuid siiski laste kõne arengu seisukohast lähimasse arenguvalda jäävaid lausemalle. Eri autorite (Burchinal et al., 2002; Howes et al., 2008) hinnangul on selline mõju püsiva iseloomuga, st see avaldub ka üleminekul lasteaiast kooli ning mõjutab õpilaste keelelisi osaoskusi koolieas.

Vähem on uuritud õpetaja verbaalse suhtluse mõju õpilaste emakeeleoskustele koolieas. Uurijaid on huvitanud peamiselt see, milliseid keelelisi vahendeid kasutavad õpetajad aruteludes, mis tüüpi küsimusi nad õpilastele esitavad ning kuidas selgitavad uusi mõisteid (Garcia et al., 2011; Lyle, 2008; Thompson, 2008). Nii leidsid Mercer ja Dawes (2014) Suurbritannia õpetajaid uurides, et esimese kooliastme klassides esitavad õpetajad teadmiste kontrollimiseks tüüpiliselt kinnisi küsimusi. Parimad akadeemilised õpitulemused emakeeles olid seevastu õpilastel, kelle õpetajad kasutasid tunnis palju arutelusid ja avatud küsimusi - mitte ainult teadmiste kontrolli eesmärgil -, toetades sel viisil ópilaste aktiivset osalust õppeprotsessis (Mercer, 2013; Mercer \& Dawes, 2014). Õpetaja juhitud arutelude positiivset mõju õpilaste argumenteerimis- ja arutlemisoskustele täheldasid ka Reznitskaya jt (2001) oma uurimuses, leides, et pärast viienädalast lugemistekstide analüüsimist paraneb 10-1laastaste õpilaste essee kirjutamise oskus.

Olulisel kohal varases koolieas on ka teadusmõistete kujundamine tavamõistetest (Võgotski, 2014; vt ka Kikas, 1997). Mõisted on alati keeleliselt vahendatud, mistõttu on õpetaja selgituste kvaliteet ja sagedus olulised tegurid nende kujunemisel. Efektiivse keelekasutusega õpetaja tunneb laste mõistete arengu taset ja kujundab neid lähimas arenguvallas, st seostades olemasolevaid teadmisi ja kujutlusi uutega ning esitades ja ühendades mõistete olulisi tunnuseid (Võgotski, 2014). Howesi jt (2008) uuringust selgus, et lapsed, kelle õpetajad kujundavad teadlikult mõisteid ja selgitavad sõnade tähendusi, saavutavad häid akadeemilisi tulemusi.

Kuigi õpetajate verbaalse ja mitteverbaalse suhtluse seoseid on uuritud vähe, leidub positiivseid näiteid selle kohta, kuidas klassiõpetajad toetavad õppeprotsessi erinevate kehaasendite, žestide ja pilguga (vt Alibali \& Goldin-Meadow, 1993; Mihkels, 2013). Sime (2008) uuring näitas, et žestid aitavad õpilastel paremini mõista õpetaja edastatut, kuna need mõjuvad tagasisidena. Näiteks paranes 8-9aastaste õpilaste emakeele sõnavara märkimisväärselt, kui õpetajad kasutasid žeste liikumisverbide õpetamisel (De Nooijer, van Gog, Paas, \& Zwaan, 2014).

Kokkuvõtteks saab väita, et praeguseks on üsna palju teada õpetaja suulise keelekasutuse vormidest ja funktsioonidest klassis. Samuti ollakse 
veendunud õpetaja ja õpilase suhtluskoostöö kvaliteedi mõjus õpilaste akadeemilisele edukusele. Vähem on teada, milline on õpetaja keele- ja suhtluseeskuju mõju õpilase arengu erinevatele näitajatele. Vastus sellele küsimusele võimaldaks selgemalt kirjeldada viise, kuidas õpetaja saab mõjutada õppimist. Siinne artikkel keskendub ühele kitsamale aspektile: õpetaja harjumuslikule suhtlusstiilile tunnis ja sellele, kuidas see mõjutab õpilaste akadeemilisi tulemusi emakeeles.

\section{Empiirilise uurimuse eesmärgid ja hüpoteesid}

Õpetaja suhtlusstiil tunnis aitab kaasa õpilaste keeleoskuste arendamisele (Pianta et al., 2008). Selles artiklis käsitletakse suhtlusstiili kui erinevate verbaalse ja mitteverbaalse suhtluse komponentide kombinatsiooni, mis realiseerub õppetunnis kui eri tüüpi suhtlusolukorras. Suhtluskomponentide teadlik ja paindlik kasutamine võimaldab toetada õpilaste metakognitsiooni ja keeleoskuste arengut (Zepeda, Richey, Ronevich, \& NokesMalach, 2015), kuid selle mõju õpilaste akadeemilisele edukusele on uuritud vähe (Orlich, Harder, Callahan, Trevisan, \& Brown, 2010). Uurimuse eesmärk on hinnata eesti klassiõpetajate suhtlusstiili emakeeletunnis ja selgitada välja selle seosed õpilaste keeleoskusega. Uurimuses püstitatakse järgmised ülesanded ja hüpoteesid.

1. Hinnata, kuidas klassiõpetajad kasutavad verbaalse suhtluse komponente. Esimeses kooliastmes tegeldakse palju õpilaste keeleoskuse arendamisega, sh teksti lugemise ja mõistmisega, õigekirja ja suhtlemisoskuse kujundamisega (Põhikooli riiklik õppekava, 2010). Oluline on nende oskuste teadvustatus (nt õigekirjareeglite kasutamine, esmased oskused töös tekstiga), mis kujuneb õpetaja suhtluskoostöös õpilastega (Mercer, 2013; vt ka Võgotski, 2014). See eeldab õpetajalt oskust jälgida enda keelekasutust ja suunata õpilaste oma (Hamre \& Pianta, 2010). Võib oletada, et õpetajad kasutavad verbaalse suhtluse komponente erineval määral. Tuginedes varasematele uurimustele, eeldatakse artiklis, et eesti õpetajad kasutavad klassis piiratud määral vestlusi ja küsimuste valik vestluses on suhteliselt juhuslik. Samuti tegelevad õpetajad vähe sõnatähenduse kujundamisega ega kasuta keelt enda ja õpilaste tegevuse, sh mõttetegevuse kommenteerimiseks (Mercer \& Dawes, 2014; Salminen, 2014).

2. Leida eri suhtlusstiiliga ópetajate rühmad. Õpetajate oskused toetada õppedialoogis teemakohast vestlust ja pakkuda õpilastele võimalusi oma mõtete jagamiseks on erinevad (Mercer \& Dawes, 2014; Salminen, 
Hännikäinen, Poikonen, \& Rasku-Puttonen, 2013; Webb, Nemer, \& Ing, 2006). Võib oletada, et klassiõpetajate valimis avalduvad rühmad, mis erinevad üksteisest suhtluskomponentide kasutuse poolest. Varasemates uurimustes (LoCasale-Crouch et al., 2007; Salminen, 2014) on tuvastatud õpetaja-õpilase suhtluskoostöö profiile, kuid verbaalse ja mitteverbaalse suhtluse komponentide kasutuse mitmekesisuse alusel pole selliseid profiile varem püütud leida.

3. Analüüsida õpetajate mitteverbaalseid suhtlusviise. Toetudes varasematele mitteverbaalse ja mitmeviisilise suhtluse uuringutele (Alibali \& Goldin-Meadow, 1993; De Nooijer et al., 2014; Merola \& Poggi, 2003; Sime, 2008), võib oletada, et erineva verbaalse suhtlusprofiiliga õpetajad eristuvad mitteverbaalse suhtluse komponentide kasutamise poolest. Mitteverbaalse suhtluse komponentide aktiivsemat kasutust eeldatakse nende õpetajate rühmas, kes kasutavad mitmekesiseid verbaalse suhtluse komponente.

4. Selgitada välja, mil määral seostuvad klassiõpetajate suhtlusprofiilid nende ópilaste emakeeleoskusega. Toetudes varasematele uurimustele (Mercer, 2013; Orlich et al., 2010; Reznitskaya et al., 2001; Salminen, 2014), võib eeldada, et erineva suhtlusprofiiliga õpetajate puhul on õpilaste tulemused erinevad. Artiklis lähtutakse hüpoteesist, et paremaid tulemusi saavutavad õpilased nende õpetajate rühmades, kes kaasavad õpilasi rohkem õpidialoogi ning kasutavad erinevaid suhtluskomponente paindlikult. Õpilaste madalamat keeleoskuse taset võib oodata nende õpetajate rühmas, mis paistab silma suhtluskomponentide väikese mitmekesisuse poolest.

\section{Metoodika}

\section{Valim}

Uuringus osalenud klassiõpetajate ja õpilaste andmed koguti üle-eestilise uurimisprojekti raames (Toomela, 2010). Koolide valikul arvestati nende piirkondlikku paiknemist ja asukohta (maa- ja linnakool), kooli tüüpi (põhikool ja gümnaasium) ning klasside valikul suurust (väikesed ja suured klassid, liitklassid). Kõik õpetajad õpetasid lapsi Eesti põhikooli riikliku õppekava järgi. Selles artiklis analüüsitakse 24 kooli klassiõpetajate emakeeletunde seostatuna nende õpilaste emakeeleoskusega.

Artiklisse valiti 46 klassiõpetaja emakeeletunni videosalvestised. Õpetajate suhtlusstiilide hindamiseks kasutati 3. klassi sügisel lindistatud tunde. Analüüsidest jäeti välja kolm õpetajat, kelle emakeeletunnid 
ei vastanud uurimuse eesmärkidele (nt ainetund kestis 90 minutit; õpilased tegid 40 minutit kontrolltööd ja õpetaja-õpilaste vahel suhtluskoostööd ei toimunud). Õpetajate keskmine vanus oli 42,55 aastat, $S D=8,36$ $(N=39 ; \min =26$ aastat; $\max =61$ aastat $)$ ja keskmine õpetamiskogemus 18,11 aastat, $S D=9,67(N=42$, $\min =1 ; \max =39)$. Neli õpetajat ei märkinud oma vanust ja üks õpetaja oma õpetamiskogemust. Vaadeldud õpetajate hulgas oli 45 naist ja 1 mees. Kõik õpetajad õpetasid valimisse kuulunud õpilastele emakeelt 1.-3. klassis.

Õpilaste emakeeleoskust mõõdeti samuti 3. klassi sügisel. Õpilasi oli uuringus kokku 789 , neist $51 \%$ olid poisid ja $49 \%$ tüdrukud. Kõigi õpilaste emakeel oli eesti keel. Õpilaste keskmine vanus 3. klassi sügisel oli 9,08 aastat, $S D=0,37$. Artikli analüüsidesse kaasati ainult need 611 õpilast, kes sooritasid emakeeletesti ja kelle õpetajaid hinnati.

\section{Mõõtevahendid ja protseduur}

\section{Struktureeritud vaatlus}

Õpetajate suhtlusstiilide hindamiseks kasutati struktureeritud vaatlust mõõtevahendi The Classroom Assessment Scoring System juhendi järgi (CLASS; Pianta et al., 2008). CLASS on valideeritud mõõtevahend, mis on mõeldud klassiruumi kvaliteedi kirjeldamiseks. Selle üks osa - õppeprotsessi toetamine - hõlmab kolme valdkonda: mõistete kujundamist, tagasisidet õpilasele ja õpetaja keelelist mudeldamist (ingl language modeling). Selles artiklis keskendutakse ainult keelelisele mudeldamisele, mis koos mitteverbaalse suhtlusega moodustab õpetaja tunnisuhtlusstiili ehk -profiili. See mõõtevahendi osa võimaldab hinnata keelekasutuse kvantiteeti ja kvaliteeti ning koosneb viiest skaalast (11 tunnusest), mida edaspidi nimetatakse verbaalse suhtluse komponentideks.

Vestluse sageduse skaalal (3 tunnust) jälgitakse õpetaja ja õpilaste vooruvahetust õppedialoogis, õpetaja reageerimist õpilaste vastustele ja õpilaste omavahelist vestlust (nt õpetaja palub lapsel õpetada oma pinginaabrit). Küsimuste valiku skaalal (2 tunnust) hinnatakse õpilastele esitatud küsimuste ja nende vastuste taset (nt mil määral õpetaja esitab mõtlemist stimuleerivaid miks- ja kuidas-küsimusi). Kordamise ja täiendamise skaala (2 tunnust) hõlmab õpilaste vastuste kordamist, täiendamist ja laiendamist (nt õpetaja kordab lapse vastust osaliselt ja/või lisab enda kommentaari). Tegevuste kommenteerimise skaalal (2 tunnust) hinnatakse, kas õpetaja saadab enda ja õpilaste tegevusi selgitava jutuga (nt Ma kirjutan kõik tähed ühekordselt, sest te tuletasite mulle meelde kaashäälikü̈hendi reegli). 
Keelekasutuse raskusastme skaalal (2 tunnust) mõõdetakse õpetaja sõnavara ja lausemallide kasutuse variatiivsust, oskust seostada õpidialoogis uusi sõnu tuttavate sõnade ja varasemate teadmistega. Keelekasutuse raskusastet hinnati ekspertmeetodil, arvestades sõnade esinemissagedust selles vanuses laste keelekeskkonnas, tähenduste abstraktsust, ülekantust, keelendite kujundlikkust jne. Varasemates uurimustes on mõõtevahendi skaalade reliaablus tunnistatud väga heaks (vt Hamre, Mashburn, Pianta, \& Downer, 2006, viidatud Pianta et al., 2008 järgi; Salminen, 2014).

CLASSi mõõtevahendi juhendi järgi jaotati üks ainetund (40-45 min) kaheks vaatlustsükliks (20 min), mida hinnati eraldi. Kahe tsükli vahel tehti viieminutine paus, mil vaatleja fikseeris oma tähelepanekud ja andis hinnangu õpetaja iga vaadeldava tunnuse kohta. Kokku oli 92 vaatlustsüklit (46 õpetajat). Hindamiseks kasutati seitsmepallist Likerti skaalat, arvestades õpetaja keelelise suhtluse avaldumise sagedust ja taset: 1-2 madal, 3-5 - keskmine ja 6-7 - kõrge tase. Uuringus hinnati iga tunnust kaks korda, kummaski vaatlustsüklis eraldi. Iga skaala väärtuste arvutamiseks ühendati esimeses ja teises vaatlustsüklis antud hinnangud ning arvutati nende mediaan $(\min =1, \max =7)$.

Õpetajate emakeeletunnid salvestati klassiruumis, enamik neist kahe videokaameraga, eest- ja tagantvaates. Vaatluste tegemiseks omandas üks artikli autoritest esmalt oskuse kasutada CLASSi mõõtevahendit ühenädalasel väljaõppel Soomes, seejärel rakendati Soome treeningu eeskuju praeguse artikli aluseks olevas uuringus. Esiteks omandasid autorid teadmised õpetajate hindamisest vaatlusmõõdiku juhendi järgi (kasutades nii ingliskeelset originaali kui ka eestikeelset tõlget). Teiseks hinnati ühiselt ühe klassiõpetaja emakeeletunni salvestust. Selleks hindas iga vaatleja õpetajat kõigepealt individuaalselt, seejärel võrreldi kolme vaatleja hinnanguid ja arutati läbi erinevused. Toetudes juhendis esitatud kirjeldustele, saavutati konsensus. Kolmandas etapis vaatles iga vaatleja ühe nädala jooksul 4-5 õpetaja videosalvestusi, seejärel korraldati teine ühine videovaatlus. Selle põhieesmärk oli võrrelda uurijate hinnangute kooskõla ja püsivust ajas (Cohen, Manion, \& Morrison, 2007). Järgnes uuringu neljas, põhietapp, mil kolme nädala jooksul vaadeldi kõiki uuringu kriteeriumidele vastavaid videosalvestusi (vt valimi kirjeldust). Neid õpetajaid, keda hindas kaks uurijat, oli kokku 26\%. Kahe vaatleja hinnangute kooskõla kirjeldamiseks ordinaalskaalal arvutati Krippendorffi alfa. Tulemusi interpreteeriti Landise ja Kochi kriteeriumide järgi (vt Stehman, 1997): suurepärane $(>0,81)$, tugev $(0,61-0,80)$, mõõdukas $(0,41-0,60)$, rahuldav $(0,21-0,40)$ ja väike reliaablus $(<0,20)$. Kahe vaatleja hinnangute kooskõla oli mõõdukas (120 hinnangut, $\alpha=0,55)$. 


\section{Multimodaalne videoanalüïs}

Multimodaalset videoanalüüsi kasutati õpetajate mitmeviisilise suhtluse uurimiseks. Arvesse võeti indiviidi suhtlusviiside jaotust Poggi (2002) järgi. Mitteverbaalse suhtluse liikidest olid vaatluse all õpetajate käežestid, prosoodia ja viseemid. Käežestidest jälgiti osutavaid, tähelepanu nõudvaid (nimetissõrmega) ja ikoonilisi žeste (kujutavad referenti mingi omaduse kaudu), samuti pöörati tähelepanu käte asetusele seismisel ja kõndimisel. Prosoodia puhul hinnati õpetaja hääletooni. Samuti tehti kindlaks viseemide esinemine või puudumine suhtlemisel. Analüüsitavaid videolõike vaadati korduvalt, valikud tehti esilduvuse pinnalt, st jälgides, milliseid viise esines asjaomases kontekstis rohkem. Videoanalüüsi meetodi omandamiseks läbis üks autoritest koolituse rahvusvahelise koostööprojekti „PlaceME: Place, mediated discourse and embodied interaction” (20062009) raames.

\section{Õpilaste emakeeletest}

Õpilaste emakeeletesti kasutati eesmärgiga välja selgitada 3. klassi laste emakeeleoskused. Testi väljatöötamisel toetuti Bloomi hierarhilise taksonoomia edasiarendusele (Krathwohl, 2002), emakeele ainekava nõudmistele ja riiklikele tasemetöödele (vt ka Uibu \& Männamaa, 2014). Keeletestis oli kokku seitse ülesannet (34 allülesannet). Kolm ülesannet mõõtsid õpilaste arusaamist tekstist ja sõnavara tundmist. Teksti mõistmise lihtsamas ülesandes $(n=8)$ pidi õpilane oskama tekstist infot leida. Teksti põhjal oli vaja otsustada, kas ülesandes esitatud laused on õiged või väärad. Teksti mõistmise keerukamas ülesandes oli tarvis teksti põhjal ühendada kaks osalauset $(n=6)$. See ülesanne nõudis õpilaselt oskust integreerida infot ümbersõnastatud kujul. Sõnavaraülesandega mõõdeti õpilaste sõnatähenduse tundmist $(n=3)$. Ülesandesse valitud sõnad pärinesid samast tekstist ja olid teksti sisu mõistmise seisukohalt olulised.

Õpilaste õigekirja põhiteadmisi ja reeglite tundmist hinnati kolme ülesandega. Sõnaliigiülesandes $(n=9)$ pidi õpilane leidma tekstist omadussõnu ning elus ja eluta olendeid märkivaid nimisõnu. Õigekirjaülesandes tuli ópilasel parandada keelevead ja ühendada keelendid ülesandes esitatud sobiva reegliga (8 keelendit, 4 reeglit). Liitsõnaülesandega, mille korral pidi õpilane leidma tekstist liitsõnu $(n=3)$, mõõdeti liitsõna tundmise oskust. Üks ülesanne eeldas teadmist, mis on lause: õpilane pidi tegema otsuse, mitu lauset esineb tekstis $(n=1)$. Emakeeletesti üldskoor arvutati õpilaste õigete vastuste põhjal. Testi sisereliaablus oli hea (Cronbachi $\alpha=0,83$ ). 
Õpilaste emakeeletestid saadeti koolidesse postiga kinnistes ümbrikes. Testi viisid läbi valimisse kuulunud klassiõpetajad eesti keele tunni ajal. Testi täitmiseks oli õpilastel aega üks ainetund (45 minutit).

\section{Andmeanalüïs}

Andmete analüüsimisel kasutati rühma- ja indiviidikeskseid meetodeid. Eesmärk oli välja selgitada erinevused nii kogu valimi keskmiste näitajate tasemel (Cohen et al., 2007) kui ka individuaalsed erinevused sarnaste indiviidide allrühmade vahel (Bergman, Magnusson, \& El-Khouri, 2003; Bergman \& Wångby, 2014). Õpetajate mitteverbaalset suhtlust analüüsiti multimodaalse videoanalüüsi meetodiga (Goodwin, 2000; Mondada, 2006), mis baseerub kvalitatiivse mikroanalüüsi meetodil (vt LeBaron, 2008).

Kasutades statistikapaketi SPSS Statistics versiooni 22.0, tehti õpetajate ja õpilaste rühmade kohta kirjeldav statistika. Õpetajate kasutatavate tunnisuhtluse komponentide erinevusi võrreldi mitteparameetriliste Friedmani ja Wilcoxoni testidega. Õpetajate suhtlusprofiilid leiti SLEIPNER 2.1 statistikatarkvara paketti kuuluva CLUSTERi mooduli Wardi meetodi abil (Bergman et al., 2003). Klasterlahenduse valikul arvestati kolme kriteeriumi: 1) teoreetiline põhjendus; 2) mudeli EESSi näitaja $>0,75$; 3) klastrite homogeensus $<1$. Kruskali-Wallise testiga analüüsiti õpilaste jaotust erineva suhtlusprofiiliga õpetajate rühmades.

Et uurida kompleksseid seoseid õpetajate suhtlusprofiilide ja õpilaste keeleoskuste vahel, viidi läbi esimest liiki konfiguratsiooniline sagedusanalüüs (KSA) Pearsoni $\chi^{2}$-testiga (CFA, versioon 2000, von Eye, 2000). Eesmärk oli välja selgitada, kas õpetajate ja õpilaste rühmade vahel esineb tüüpilisi juhtusid (teatud tunnuste kombinatsioonid, mida esineb valimis oluliselt sagedamini, kui võiks esineda juhuslikult) ja ebatüüpilisi juhtusid (teatud tunnuste kombinatsioonid, mille esinemissagedus on juhuslikust väiksem).

\section{Tulemused}

\section{Verbaalse suhtluse komponendid}

Et kirjeldada klassiõpetajate verbaalse suhtluse stiile emakeeletunnis, tehti hinnangute kirjeldav statistika viie komponendi kohta (vt tabel 1). 
Tabel 1. Verbaalse suhtluse komponentide kirjeldav statistika

\begin{tabular}{l|c|c|c}
\hline & \multicolumn{3}{|c}{ Õpetajad $(N=46)$} \\
\hline Komponendid & $M$ & $S D$ & Keskmine astak \\
\hline Vestluse sagedus & 4,47 & 1,92 & 3,34 \\
\hline Küsimuste valik & 4,23 & 1,82 & 2,78 \\
\hline Kordamine & 4,69 & 1,69 & 3,61 \\
\hline Kommenteerimine & 3,53 & 1,73 & 1,87 \\
\hline Keelekasutus & 4,50 & 1,65 & 3,40 \\
\hline
\end{tabular}

Kasutades mitteparameetrilist Friedmani testi, võrreldi õpetajate verbaalse suhtluse komponentide rakendamist. Selgus, et klassiõpetajad erinesid statistiliselt oluliselt komponentide eelistuste poolest rühma keskmiste tulemuste tasemel, $\chi^{2}=41,29, d f=4, p<0,001$. Kõige vähem kasutasid õpetajad emakeeletunnis iseenda ja õpilaste tegevuste kommenteerimist, kõige rohkem aga õpilaste vastuste kordamist ja täiendamist. Paariti võrdlusest Wilcoxoni testiga ilmnes, et kordamise ja keelekasutuse skoorid olid statistiliselt oluliselt kõrgemad kui kommenteerimise skoor, vastavalt $Z=-4,85, p<0,001$ ja $Z=-4,75, p<0,001$. Samuti anti võrdluses tegevuste kommenteerimisega oluliselt kõrgemad hinnangud vestluse sagedustele, $Z=-4,12, p<0,001$, ja küsimuste valikule, $Z=-3,21, p=0,001$. Seevastu õpetajate küsimuste valiku taset hinnati oluliselt madalamaks kui õpilaste vastuste kordamist ja täiendamist, $Z=-2,69, p=0,007$.

\section{Õpetajate suhtlusprofiilid}

Eespool selgus, et rühma keskmise tulemuse tasemel erinesid klassiõpetajad oma suhtluskomponentide kasutamise sageduse poolest. Et selgitada välja süstemaatilised erinevused õpetajate keelelises suhtluses, kasutati indiviidikeskseid analüüse (Bergman et al., 2003). Selleks leiti esmalt RESIDUE mooduli abil erindid. Kaks õpetajat, kelle kõigi suhtluskomponentide skoorid olid erandlikult kõrged, jäeti välja ja seejärel tehti hierarhiline klasteranalüüs (CLUSTERi mooduli Wardi meetod). 44 õpetajat jaotusid klastritesse viie suhtluskomponendi standardiseeritud tulemuste põhjal. Mudeli headust hinnati teoreetilise põhjenduse, EESSi näitaja $(=80,47)$ ja klastrite homogeensuse $(<0,72)$ järgi. Välja valiti neljaklastriline lahendus (vt tabel 2). 
Tabel 2. Suhtlusprofiilide kirjeldav statistika

\begin{tabular}{l|c|c|c|c|c|c|c|c|c|c|c}
\hline \multicolumn{2}{l|}{} & \multicolumn{2}{c|}{$\begin{array}{c}\text { Vestluse } \\
\text { sagedus }\end{array}$} & \multicolumn{2}{c|}{$\begin{array}{c}\text { Küsimuste } \\
\text { valik }\end{array}$} & \multicolumn{2}{c|}{ Kordamine } & \multicolumn{2}{c|}{$\begin{array}{c}\text { Kommen- } \\
\text { teerimine }\end{array}$} & \multicolumn{2}{c}{$\begin{array}{c}\text { Keele- } \\
\text { kasutus }\end{array}$} \\
\hline Klaster & $N=44$ & $M$ & $S D$ & $M$ & $S D$ & $M$ & $S D$ & $M$ & $S D$ & $M$ & $S D$ \\
\hline KL1 & 11 & 2,18 & 0,75 & 1,95 & 0,65 & 2,23 & 0,56 & 1,64 & 0,67 & 2,5 & 0,92 \\
\hline KL2 & 13 & 4,12 & 1,21 & 4,46 & 1,22 & 4,46 & 0,75 & 2,77 & 0,99 & 4,27 & 0,97 \\
\hline KL3 & 13 & 6,42 & 0,45 & 6,0 & 0,68 & 6,35 & 0,43 & 5,35 & 0,83 & 6,38 & 0,46 \\
\hline KL4 & 7 & 5,86 & 0,8 & 4,86 & 0,9 & 5,79 & 0,64 & 4,43 & 0,61 & 4,71 & 0,39 \\
\hline
\end{tabular}

Profiilide tõlgendamisel arvestati muutuja standardiseeritud skoori: $Z>0,5$ kõrge tase; $Z$ vahemikus -0,5 kuni 0,5 - keskmine tase; $Z<-0,5$ - madal tase. Eristunud nelja profiilirühma suhtluskomponentide skoorid olid teiste profiilirühmadega võrreldes kas oluliselt kõrgemal või madalamal tasemel (vt joonis 1 ja tabel 3).

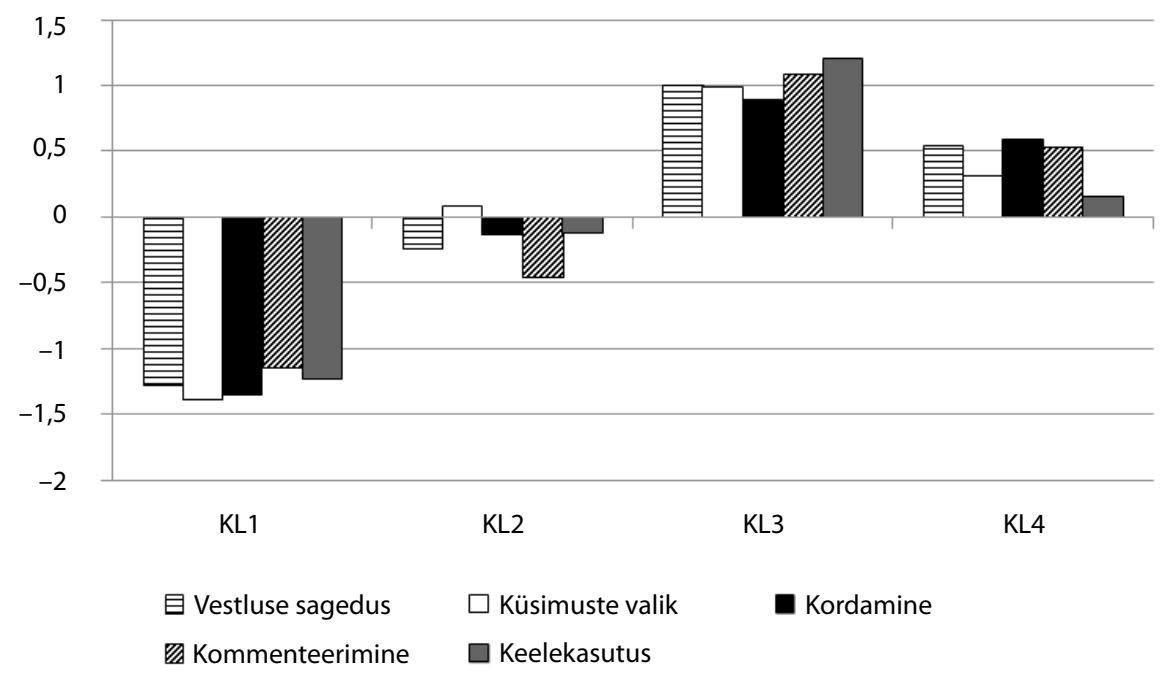

Joonis 1. Klassiõpetajate profiilid suhtluskomponentide alusel (KL - klaster) 
Tabel 3. Profiilide kirjeldused standardiseeritud skooride järgi

\begin{tabular}{|c|c|c|c|c|c|c|c|c|c|c|}
\hline \multirow{2}{*}{$\begin{array}{l}\text { Profiili } \\
\text { kirjeldus }\end{array}$} & \multicolumn{2}{|c|}{$\begin{array}{l}\text { Vestluse } \\
\text { sagedus }\end{array}$} & \multicolumn{2}{|c|}{$\begin{array}{l}\text { Küsimuste } \\
\text { valik }\end{array}$} & \multicolumn{2}{|c|}{ Kordamine } & \multicolumn{2}{|c|}{$\begin{array}{l}\text { Kommen- } \\
\text { teerimine }\end{array}$} & \multicolumn{2}{|c|}{ Keelekasutus } \\
\hline & $M$ & TG & $M$ & TG & $M$ & $T G$ & $M$ & $T G$ & $M$ & $T G$ \\
\hline $\begin{array}{l}\mathrm{KL} 1 \text { - väike } \\
\text { mitmekesisus }\end{array}$ & $-1,29$ & $\begin{array}{l}\text { Ma- } \\
\text { dal }\end{array}$ & $-1,39$ & $\begin{array}{l}\text { Ma- } \\
\text { dal }\end{array}$ & $-1,35$ & $\begin{array}{l}\text { Ma- } \\
\text { dal }\end{array}$ & $-1,15$ & $\begin{array}{l}\text { Ma- } \\
\text { dal }\end{array}$ & $-1,23$ & $\begin{array}{l}\text { Ma- } \\
\text { dal }\end{array}$ \\
\hline $\begin{array}{l}\text { KL2 - kesk- } \\
\text { mine mitme- } \\
\text { kesisus }\end{array}$ & $-0,25$ & $\begin{array}{l}\text { Kesk- } \\
\text { mine }\end{array}$ & 0,08 & $\begin{array}{l}\text { Kesk- } \\
\text { mine }\end{array}$ & $-0,14$ & $\begin{array}{l}\text { Kesk- } \\
\text { mine }\end{array}$ & $-0,47$ & $\begin{array}{l}\text { Kesk- } \\
\text { mine }\end{array}$ & $-0,12$ & $\begin{array}{l}\text { Kesk- } \\
\text { mine }\end{array}$ \\
\hline $\begin{array}{l}\text { KL3 - suur } \\
\text { mitmekesisus }\end{array}$ & 1,0 & Kõrge & 0,98 & Kõrge & 1,08 & Kõrge & 0,91 & Kõrge & 1,2 & Kõrge \\
\hline $\begin{array}{l}\text { KL4 - vahel- } \\
\text { duv mitme- } \\
\text { kesisus }\end{array}$ & 0,53 & Kõrge & 0,32 & $\begin{array}{l}\text { Kesk- } \\
\text { mine }\end{array}$ & 0,59 & Kõrge & 0,53 & Kõrge & 0,15 & $\begin{array}{l}\text { Kesk- } \\
\text { mine }\end{array}$ \\
\hline
\end{tabular}

Märkus. TG - tasemegrupp.

Võrdselt palju klassiõpetajaid (29,5\%) paigutus profiilirühma, kus kõigi suhtluskomponentide kasutamise taset hinnati kas keskmiseks või teiste õpetajatega võrreldes kõrgeks. Nii iseloomustas keskmise mitmekesisusega profiilirühma kuulunud õpetajaid suhtluskomponentide ebajärjekindel ja piiratud kasutus (KL2). Suure mitmekesisusega suhtlusprofiili korral oli tegemist klassiõpetajatega, kes kasutasid eri komponente palju (KL3). Märkimisväärselt suur hulk - neljandik õpetajatest - liigitus väikese mitmekesisusega profiilirühma (KL1), mida iseloomustas kõigi viie komponendi vähene kasutus või ei kasutanud need õpetajad mõnd komponenti üldse $(Z$-skoor $<-1)$. Kõige väiksema, vahelduva mitmekesisusega profiilirühma (KL4) moodustas seitse õpetajat, kes kasutasid eri suhtluskomponente keskmisel ja keskmisest mõnevõrra kõrgemal tasemel (Z-skoor vahemikus $0,15-0,59)$. Nende tunnisuhtlusstiilile oli omane ebajärjekindlus eri komponentide kasutuses.

\section{Õpetajate profiile iseloomustavad mitteverbaalse suhtluse komponendid}

Nelja profiilirühma kuulunud õpetajate mitteverbaalse suhtluse komponendid varieerusid teatud tüüpi žestide intensiivsema kasutuse, hääletooni erinevuste ja viseemide esinemise poolest. Väikese mitmekesisusega profiilirühma esindanud õpetajad kasutasid vähe nii osutavaid žeste õpilaste abistamiseks või vastama suunamiseks kui ka ikoonilisi žeste sõnade seletamiseks. Seevastu kasutasid nad nimetissõrme õpilaste hoiatamiseks 
[Õ (tõstab sõrme): Teil on töö tegemiseks aega ainult neli minutit] ning hoidsid seistes käsi sageli ees või kõndides seljal. Nad tavatsesid kasutada vastuvaidlemist mittesallivat hääletooni (tüüpiline tunnus) ning ei kiitnud ega tunnustanud õpilasi meeldiva hääletooniga (ebatüüpiline tunnus). Naeratust ei märgatud nende õpetajate puhul üldse.

Keskmise mitmekesisusega profiilirühma kuulunud õpetajad kasutasid väikese mitmekesisusega profiilirühma esindanud õpetajatega võrreldes osutavat žesti laste abistamiseks rohkem [nt Õ parandab tüdrukut vaikselt: Inimene on „kes”, ja osutab sõrmega vihikusse], kuid mitte õpilastelt vastust oodates. Selle rühma õpetajad ei seisnud käed rinnal, kuid mõnevõrra märgati, et nad hoidsid kõndides või seistes käsi seljal. Ikoonilisi žeste kasutasid selle profiili õpetajad rohkesti [Õ: Kas Nublu kartis ka? Kui leegid olid tohutud (kahe käega teeb suure illustreeriva kaare)]. Nad kiitsid õpilasi järsema tooniga ning väljendasid märkuste tegemisel end peamiselt verbaalselt. Nad naeratasid rohkem kui väikese mitmekesisusega profiilirühma kuulunud õpetajad.

Suure mitmekesisusega profiilirühma esindanud õpetajad kasutasid ópilaste abistamiseks osutavaid žeste väga vähe. Nad tegid seda rohkem siis, kui soovisid saada õpilastelt vastuseid [nt Õ: Nii, sina (osutab jällegi käega sellele lapsele, kes peab vastama)]. Nimetissõrme õpilaste hoiatamiseks nad ei kasutanud, samuti asetasid nad käsi ette ja seljale väga harva. Ikoonilisi žeste tegid õpetajad selles rühmas üsna vähe, kuid õpilasi kiitsid nad sageli rõõmsal hääletoonil. Selle rühma õpetajad naeratasid õpilastele sageli.

Kõige väiksema, vahelduva mitmekesisusega profiilirühma kuulunud õpetajatel osutavate žestide kasutamist laste abistamiseks ei täheldatud. Seevastu tegid nad keskmisel määral käeviipeid nende õpilaste suunas, kes pidid vastama. Nimetissõrme tõstsid õpetajad õpilaste tähelepanu haaramiseks, kuid mitte hoiatamiseks. Ikoonilisi žeste kasutasid selle rühma õpetajad vähe. Nad kiitsid tunnis õpilasi sageli, kasutades selleks rahulikku hääletooni, samuti naeratasid nad sageli.

\section{Õpetajate suhtlusprofiilide seosed õpilaste keeleoskustega}

Õpetajate suhtlusprofiilide ja õpilaste keeleoskuste seoste uurimisel lähtuti eeldusest, et erineva suhtlusprofiiliga klassiõpetajate õpilased erinevad oma emakeeleoskuse poolest. Analüüsidest jäeti välja õpilased, kes ei sooritanud emakeeletesti või kellel oli jäänud enamik ülesannetest lahendamata (üldskoor $\leq 5$ ). Õpilaste emakeeletesti keskmine tulemus 3. klassis oli 25,17 punkti, $S D=6,81(N=611, \min =6$, $\max =35)$. Kasutades KruskaliWallise testi, selgus, et rühma keskmise tulemuse alusel erinesid nelja 
suhtlusprofiili õpetajate õpilased statistiliselt oluliselt oma keeleoskuste poolest, $\chi^{2}=7,12, p=0,008$. Et saada ülevaade, millise keeleoskuste tasemega õpilased on tüüpilised millise tunnisuhtlusstiiliga klassiõpetajatele, tehti Pearsoni $\chi^{2}$-testiga esimest järku KSA analüüs. Selleks jaotati õpilased keeletesti tulemuste standardiseeritud skoori alusel esmalt kolme rühma: $Z>0,5$ - kõrge tase, $-0,5<Z<0,5$ - keskmine tase, $Z<-0,5$ - madal tase. Üsna võrdselt õpilasi jaotus keskmise ja kõrge keeleoskuste tasemega rühmadesse (vastavalt 37,2\% ja 35,1\%). Vähem oli neid õpilasi, kelle keeleoskuste tase oli madal (27,7\%). Seejärel analüüsiti õpilaste tulemusi koos õpetaja profiilirühmaga: eristus kaks tüüpilist ja kaks ebatüüpilist kombinatsiooni (KSA mudel: $\chi^{2}=35,87, d f=6, p<001$ ).

Vastupidi hüpoteesile ilmnes, et väikese mitmekesisusega profiilirühma kuulunud klassiõpetajatel oli oluliselt rohkem kõrge keeleoskuste tasemega õpilasi, kui juhuslikult oodatud, $\chi^{2}=10,47, p=0,001, f o=84, f e=59,12$ (Bonferroni teisendusega). Seevastu õpetajatel, kes esindasid suure mitmekesisusega suhtlusprofiili, oli rohkem kehvade tulemustega õpilasi, kui võinuks juhuslikult oodata, $\chi^{2}=5,88, p=0,015, f o=74, f e=55,87$. Üks ebatüüpiline kombinatsioon ilmnes väikese mitmekesisusega profiilirühma kuulunud õpetajate ja madala emakeeleoskuste tasemega õpilaste vahel, $\chi^{2}=9,02, p=0,003, f o=46,47, f e=26$. Nimelt, neil õpetajatel, kes kasutasid kõiki suhtluskomponente harva või mõnd üldse mitte, oli oodatust vähem kehva testitulemuse saavutanud õpilasi. Teine ebatüüpiline kombinatsioon ilmnes vahelduva mitmekesisusega profiilirühma kuulunud õpetajate ja kõrgel tasemel testi sooritanud õpilaste vahel, $\chi^{2}=4,33, p=0,037, f_{0}=29$, $f e=42,58$. Niisiis oli õpetajatel, kes kasutasid erinevaid suhtluskomponente keskmisel või kõrgel tasemel, oodatust vähem õpilasi, kes sooritasid testi hästi.

\section{Arutelu}

Uurimuses hinnati eesti klassiõpetajate suhtlusstiile emakeeletundides ja selgitati välja nende seosed õpilaste keeleoskusega. Kasutades rühma- ja indiviidikeskseid analüüse ning multimodaalset videoanalüüsi, leiti erinevused nii rühma keskmiste tulemuste tasemel kui ka erinevate suhtlusprofiilide vahel. Õpetajate suhtlusstiilid ja õpilaste emakeeletesti tulemused ei seostunud ootuspäraselt. Õpetajatel, keda iseloomustas teistega võrreldes mitmekesine suhtluskomponentide kasutus, oli siiski oodatust rohkem vähese keeleoskusega õpilasi. Seevastu vähevariatiivse ja erinevate suhtluskomponentide väikese kasutussagedusega õpetajatel oli oodatust rohkem õpilasi, kes sooritasid emakeeletesti hästi. 


\section{Suhtluskomponentide kasutamine emakeeletunnis}

Kinnitust leidis oletus, et õpetaja suhtlusstiil tunnis varieerub oluliselt erinevate komponentide lõikes, samuti erinevad õpetajad üksteisest sama komponendi eelistamise poolest. Õpetajate keelekasutuse suurt varieeruvust õppeprotsessi toetamisel on varem kirjeldanud mitmed uurijad (Howes et al., 2008; Salminen, 2014). Võrreldes teiste komponentidega kasutasid klassiõpetajad kõige sagedamini õpilaste vastuste kordamist ja täiendamist. Sarnasele tulemusele jõudsid Margutti ja Drew uuringus (2014), kus Itaalia klassiõpetajad andsid positiivset tagasisidet peamiselt vastuste osalise või täieliku kordamise kaudu. Vestluspartneri vastuse kordamine ja täiendamine näitavad ka aktiivset kuulamist (Krips, 2011), mis soodustab vooruvahetust suhtlemisel ja stimuleerib tunnidialoogi kaudselt (Lyle, 2008).

Kooskõlas oletusega, et õpetajad ei kommenteeri palju enda ja õpilaste tegevusi klassis, selgus, et klassiõpetajad väljendasid kuuldavalt oma mõtteid ning saatsid selgitavate kommentaaridega enda ja õpilaste tegevusi oluliselt harvem, kui kasutasid teisi keelelise suhtluse komponente. Selline kommenteerimine võimaldab lastel jälgida õpetaja mõttekäiku ja teadvustada enda tegevust, arendades nii eneseregulatsiooni- ja metakognitsioonioskusi (Karlep, 2005; Mercer, 2013). Vaadeldud klassiõpetajad kasutasid emakeeletundides kõnet nende oskuste kujundamise eesmärgil piiratult. Seega võib oletada, et võrreldes kommunikatiivse funktsiooniga teadvustasid õpetajad vähe kõne kognitiivset funktsiooni.

Vaatlejate hinnangul vastasid nii vestluste sagedus kui ka õpetaja keelekasutuse raskusaste keskmisele tasemele, st õpetajad rääkisid õpilastega regulaarselt, kuid vestlused piirdusid tüüpiliselt ühe või kahe vooruvahetusega (küsimus - vastus - küsimus - vastus või küsimus - vastus - õpetaja tagasiside). Pikemad vestluse episoodid ei olnud selle uuringu valimi puhul tüüpilised. Üldjuhul alustas vestlust õpetaja, kusjuures õpilaste algatusi ta alati ei arvestanud (vt ka Pianta et al., 2008). Esitades järjepidevalt küsimusi, oli vestluses aktiivse osaleja rollis õpetaja, mitte õpilased (vt Damhuis \& Blauw, 2008). Küsimuste valiku oskuse eest said õpetajad oluliselt kõrgemaid hinnanguid kui kommenteerimise eest, samas osutus see komponent oluliselt nõrgemaks kui vastuste kordamine ja täiendamine. Kuigi õpetajad kasutasid vahetevahel avatud küsimusi, toetades sel viisil õpilaste arutlemist ja sidusat eneseväljendust, domineerisid vestlustes siiski kinnised küsimused, mida tavaliselt kasutatakse teadmiste kontrollimiseks.

Toetudes hinnangutele kolme esimese suhtluskomponendi kohta (vt tabel 1), võib väita, et eesti klassiõpetajad kasutavad tunnis enamasti sellist 
dialoogi, mis koosneb algatusest (enamasti küsimus), vastusest ja tagasisidest. Seda peetakse tüüpiliseks õpetaja-õpilase suhtluskoostöö üksuseks ka näiteks Suurbritannia algklassides (Mercer \& Dawes, 2014). Kuigi küsimuste valik sellises dialoogis oli juhuslik, väärib siiski positiivsena märkimist õpetajate viis korrata, täiendada ja sõnastada ümber laste vastuseid ( $v s$. lühihinnang vastuse õigsusele). Need tehnikad võimaldavad anda õpilastele tagasisidet, esitada korduvalt õiget vastust, rõhutada olulist ja julgustada õpilasi alternatiivse vastuse leidmisel, samuti saab nende abil muuta vastust ülejäänud klassile arusaadavamaks nii sisult kui ka vormilt (Mercer, 2000, viidatud Lyle, 2008 järgi). Uuring näitas, et õpetajate keelekasutuse raskusaste oli variatiivne, kuid uute sõnade tähenduste selgitamine üsna juhuslik. Howes jt (2008) on leidnud, et õpetajatepoolne mõistete kujundamise oskus on tugevaim akadeemilise edukuse, sh passiivse sõnavara ennustaja, kusjuures tagasisidestamisel õpilastele sellist mõju ei ole. Samas tegelesid tagasisidestamisega juhuslikult ka need klassiõpetajad, kes muude õppeprotsessi toetamise komponentide puhul saavutasid kõrgeid skoore.

Eelnevast järeldub, et klassiõpetajad olid oma oskustelt erinevad, kuid valdav osa neist kasutas erinevaid suhtluskomponente juhuslikult. Samale tulemusele jõuti lasteaiaõpetajate uurimisel (Gosse et al., 2014; Pentimonti \& Justice, 2010). Kuigi õpetajad kasutavad õpetamisel dialoogi, on selle peamine eesmärk õpilaste teadmiste kontrollimine või edastamine, mitte niivõrd arutelu tekitamine ja ühise tähenduse loomine. Tulemus on kooskõlas Lyle'i (2008) ning Merceri ja Dawesi (2014) uurimuse omaga, mille kohaselt pöörasid õpetajad vähe tähelepanu sellele, kuidas toetada oma keelekasutusega õpilaste õpioskuste ja tunnetustegevuse arengut.

\section{Erinevused õpetajate suhtlusprofiilides}

Analüüsides õpetajate suhtluskomponentide kasutamise sagedust ja varieeruvust, leiti neli profiilirühma. Positiivseks tulemuseks võib lugeda, et ligi kolmandik õpetajatest kasutas kõiki suhtluskomponente sageli ja seega oli nende tunnisuhtlusstiil mitmekesine (suure mitmekesisusega profiilirühm). Neid õpetajaid iseloomustas sage dialoogi kasutamine õppeprotsessis, sh õpilaste vahel, mida soodustas avatud küsimuste regulaarne esitamine õpilastele (Mida sa arvad? Kuidas sa seda teada said?). Õpetajate tagasiside laste vastustele ja suhtlusalgatustele võimaldas tunda õpilastel end võrdväärsete vestluspartneritena: õpetajad kuulasid lapsi aktiivselt ja mitte ainult ei korranud õpilaste vastuseid, vaid ka täiendasid ja sõnastasid neid ümber. Selliste õpetajate sõnakasutus ja lauseehitus olid kõrgel tasemel, kuid samal ajal selgitasid ja seostasid nad sõnu tuttavate sõnadega, pöörates 
seejuures tähelepanu oma kõne mõistetavusele. Seega iseloomustas mitmekesise suhtlusstiiliga õpetajaid erinevate tehnikate paindlik kasutus. On leitud, et see võimaldab õpilastel õppida arusaamisega ning omandada arutlemis- ja argumenteerimisoskust (Pianta et al., 2008; Salminen, 2014).

Suur hulk õpilasi $(n=168)$ sellist toetust õpetajalt siiski ei saanud, sest veerand õpetajatest pälvis kõigi suhtluskomponentide eest madala hinnangu (väikese mitmekesisusega profiilirühm). Neile oli iseloomulik kinniste, valdavalt lühivastuseid eeldavate küsimuste esitamine teadmiste kontrollimise eesmärgil, kusjuures tagasisidena vastuste kordamist ega täiendamist nad peaaegu ei kasutanud. Kuna vestlusi esines selle rühma õpetajate klassides harva, tingis see ka teiste suhtluskomponentide vähese kasutuse. Kui õpetaja-õpilaste suhtluskoostöö tunnis on vähene, ei ole õpilastel võimalust ka rääkida (Hamre \& Pianta, 2010). Tegevuste kommenteerimist väikese mitmekesisusega profiilirühma kuulunud õpetajad ei kasutanud. Samuti ei pööranud nad tähelepanu oma sõnakasutusele ega arvestanud õpilaste sõnatähenduste tundmise taset, st nad ei selgitanud uute sõnade tähendusi. Selle põhjal võib teha järelduse, et need õpetajad ei teadvusta ega tähtsusta keelekasutuse rolli õppeprotsessi toetamisel (Webb et al., 2006).

Kolmandik õpetajatest kasutas suhtluskomponente keskmise sagedusega (keskmise mitmekesisusega profiilirühm). Teiste komponentidega võrreldes oli neil madalaim tase enda ja õpilaste tegevuste kommenteerimises. Et õpilane saaks valida sobivaid strateegiaid (nt probleemülesannete lahendamiseks), peaks tal olema võimalik jälgida õpetaja mõtlemist (Zepeda et al., 2015). Selleks peaks õpetaja kommenteerima valjusti oma tegevusi (Pianta et al., 2008). Kõnealusele aspektile pöörasid keskmise mitmekesisusega profiilirühma kuulunud õpetajad tähelepanu juhuslikult.

Kõige väiksem rühm moodustus $16 \%$ õpetajatest, kelle keeleline suhtlus oli eri komponentide puhul kas keskmisel või sellest mõnevõrra kõrgemal tasemel (nn vahelduva mitmekesisusega profiilirühm). Suure mitmekesisusega tasemerühmast eristas neid õpetajaid küsimuste valiku ja keelelise raskusastme oluliselt madalam tase, teiste komponentide kohta said nad hindajatelt maksimumilähedasi, kuid siiski mitte maksimaalseid hinnanguid. Nimelt peaks õpetaja oskama kasutada küsimusi erinevatel eesmärkidel, kusjuures oluliseks peetakse õpilaste suunamist oma tegevust (nt õppimist) reflekteerima ja sellest rääkima, andma hinnanguid enda ja teiste tegevusele, mis soodustavad metakognitsiooni- ja refleksioonioskuste arengut (Mercer, 2013).

Niisiis, kolme rühma õpetajatele oli iseloomulik stabiilselt ühtlane tase kõigi komponentide korral (erandiks tegevuste kommenteerimine, mida 
hinnati teiste suhtluskomponentidega võrreldes madalamalt). Varasematest õpetaja-õpilase vastastikmõju uuringutest (vt Howes et al., 2009) on selgunud, et õpetajad ei toeta õpilasi samaväärselt kõikide komponentide lõikes, vaid komponentide kasutus sama rühma piires on variatiivne. Samas ei ole varem rühmitatud ópetajaid suhtluskomponentide kasutamise sageduse alusel. Võib oletada, et õpetajate profiilisisene ühtlane tase tuleneb suhtluskomponentide tugevast omavahelisest seotusest. Õpetaja, kes kasutab avatud küsimusi, kordab ja laiendab õpilaste vastuseid, selgitab uusi sõnu ja kasutab lastele jõukohast keelt, loob suhtlemist soodustava õhkkonna klassis ja stimuleerib sel viisil klassis vestlusi (sh laste algatatud vestlusi). Kirjeldatud komponentide puhul on tegemist n-ö tehnikate kompleksiga, kus ühe komponendi teadvustamine soodustab muutusi ka teiste komponentide kasutamises (Gosse et al., 2014; Mercer \& Dawes, 2014).

Praegune uurimus näitas, et $45 \%$ õpetajatest kasutab verbaalse suhtluse komponente ühtlaselt kõrgel või kõrgel ja keskmisel tasemel (suure mitmekesisusega ja vahelduva mitmekesisusega profiilirühm). Samas on üle poolte õpetajate suhtlemisoskused suhteliselt madalal tasemel ning ligikaudu veerand õpetajatest ei kasuta mõnd komponenti peaaegu üldse. On leitud, et õpilaste keeleoskuse arengu toetamiseks on oluline kombineerida erinevaid tegevusi ja strateegiaid eri tasemetel (Perry, Donohue, \& Weinstein, 2007). Kui õpetaja ei toeta oma keelekasutusega õpilaste õppimisprotsessi, st mõtlemise, eneseregulatsiooni ja metakognitsiooni arengut piisavalt (Võgotski, 2014), siis ei saa rääkida õpetajast kui keele- ja suhtluseeskujust õpilaste keelelise arengu ja teadliku keelekasutuse toetajast.

\section{Õpetajate mitteverbaalne suhtlus}

Erineva suhtlusprofiiliga õpetajad eristusid ka mitteverbaalse suhtluse komponentide kasutuse poolest. Sageli tulenes nende kasutuse eelistus tunni struktuurist (tähelepanu nõudev žest, käte asetus seismisel ja kõndimisel). Suure mitmekesisusega profiilirühma kuulunud õpetajad, kes kasutasid meeldivat, rõõmsat hääletooni ja naeratasid (st kasutasid viseeme), ning keskmise mitmekesisusega profiilirühma kuulunud õpetajad, kes tegid sõnade seletamisel palju ikoonilisi žeste, toetasid mitteverbaalsete suhtlusviisidega psühholoogilist kontakti enda ja õpilase vahel. See soodustab edastatava info paremat omandamist (vt Merola \& Poggi, 2003; Sime, 2008). Osutavate ja ikooniliste žestidega saab õpetaja toetada õppeprotsessi eri viisil. Ikooniliste žestide abil on võimalik lisada sõnadega väljendatud esemele või nähtusele visuaalset mõõdet, aidata õpilastel visualiseerida kuuldud sõna (De Nooijer et al., 2014) ning mäletada seeläbi õpitut kauem. 
Praeguse uurimuse kohaselt kasutasid osutavat žesti laste abistamiseks palju keskmise mitmekesisusega profiilirühma esindanud õpetajad, juhtides õpilase tähelepanu kas õigele kohale töövihikus või lugemisjärjele lugemikus ning kutsudes õpilast vastama.

Väikese mitmekesisusega profiilirühma paigutunud klassiõpetajad kasutasid vastuvaidlemist mittesallivat hääletooni, ei naeratanud kordagi ning tõstsid tihti nimetissõrme õpilaste hoiatamiseks. Lisaks ei osutanud nad žesti abil lapsele, kes peab vastama. Nende õpetajate kehakeel ja prosoodia ei toetanud õppeprotsessi, seega ka mitte õpilaste keelelis-kognitiivset arengut (Mercer, 2013). Selle profiilirühma õpetajad hoidsid laste iseseisva töö ajal seistes käsi ees koos ja/või kõndides seljal. Õpetajate kehaline käitumine ei soodustanud kontakti õpilastega (vt ka Krips, 2011). Väikese mitmekesisusega profiilirühma kuulunud õpetajate eriomaseks tunnuseks võib pidada nimetissõrme kasutamist eesmärgiga haarata õpilaste tähelepanu. Selline žestikasutus realiseerus positiivse õpetajapoolse strateegiana.

Kuigi enamik mitteverbaalsetest suhtlusviisidest tulenes tunni ülesehitusest, oli õpetajal võimalus teha mitmeviisilist suhtluskoostööd. Eeltoodu põhjal leidis kinnitust oletus, et verbaalse suhtluse komponente mitmekesisemalt ja paindlikumalt kasutavad õpetajad olid aktiivsemad ka mitteverbaalses suhtluses. Klassiruumi olukorras on õpetajatel kasulik teada, kuidas kasutada mitteverbaalset suhtlust sarnastes olukordades, et saavutada paremaid õpitulemusi.

\section{Õpetaja suhtlusprofiilid ja õpilaste emakeeleoskus}

Järgnevalt analüüsiti, kuivõrd eri suhtlusprofiiliga klassiõpetajate õpilased erinevad emakeeleoskuste taseme poolest. Tulemus erines eeldatust. Selgus, et kõrge keeleoskuste tasemega õpilasi esines oodatust rohkem nende õpetajate rühmas, kus erinevate suhtluskomponentide kasutamise tase oli madal (väikese mitmekesisusega profiilirühm). Sellise profiiliga õpetajatel oli ka oodatust vähem õpilasi, kes saavutasid emakeeletestis kehvemaid tulemusi. Põhjuseid võib olla mitu. Esiteks, õpilase keeleline võimekus ei sõltu üksnes õpetaja tegevusest, vaid ka pärilikkusest, ning keskkond ei seleta kõiki individuaalseid varieeruvusi laste kõne arengus (vt Chomsky, 1964; Huttenlocher et al., 2002; Võgotski, 2014). Teiseks, õpetajate vähene toetus keeleoskuste arendamisel ei takista tugevate õpilaste arengut, sest õpetaja keelekasutus on vaid üks õpikeskkonna tegur paljude muude (nt õppevara, kaasõpilaste) kõrval.

Vastupidine tulemus ilmnes mitmekesise ja varieeruva suhtlusstiiliga õpetajate rühmas (suure mitmekesisusega profiilirühm). Selliste õpetajate 
klassides õppis oodatust rohkem madala keeleoskuste tasemega õpilasi. Võimalik seletus kattub osaliselt eeltooduga: õpetaja heal tasemel keelekasutus ei kompenseeri õppekava või -vara mittevastavust n-ö nõrkade õpilaste tasemele, kuigi on leitud, et õpetaja tegevused, mis toetavad õppeprotsessi, mõjutavad õpilaste arengut otsesemalt kui näiteks õppekorraldus (Mashburn et al., 2008; Salminen, 2014). Samas peetakse nende tegurite mõju siiski oluliseks just vähem kindlustatud peredest pärit ja erivajadustega lastele (Hamre \& Pianta, 2010; Mashburn et al., 2008). Samuti võib oletada, et õpetaja kõrgel tasemel keelekasutus ei lähtu õpilaste individuaalsetest toetusvajadustest. Gleason ja Ratner (2009) väidavad, et kui õpetaja ei arvesta keelelises suhtluses õpilaste üldist kognitiivset arengut ega individuaalset eripära, ei pruugi laps õpetajast aru saada. Uurinud lasteaiaõpetajate oskusi toetada õppeprotsessi, leidis Salminen (2014), et isegi kõrge suhtlusprofiiliga õpetajad ei suutnud piisavalt arvestada laste individuaalset kognitiivset taset. Seega ei taga õpetaja heal tasemel suhtlemisoskus laste paremaid õpitulemusi emakeeles.

Ilmnes veel üks oluline ebatüüpiline kombinatsioon. Rühmas, kus õpetajad varieerisid erinevaid suhtluskomponente keskmisel või kõrgel tasemel (vahelduva mitmekesisusega profiilirühm), oli samuti emakeeletesti hästi sooritanud õpilasi oodatust vähem. Selliste mitteeeldatud seoste tõlgendamisel tuleb silmas pidada, et õpetaja suhtlusstiil on vaid üks õppeprotsessi toetamise aspekte (Pianta et al., 2008). Praegusel juhul puuduvad andmed, millised on teised vaadeldud ópetajate tunnused (nt emotsionaalne suhe lastega, õppetöö korraldus). Õpetaja keelekasutusest olulisem võib olla see, kuidas õpetaja korraldab õppetegevusi, kui selgelt ta õpilastele tööjuhiseid jagab ja mil viisil tagasisidet annab ning kuidas need õppeprotsessi toetamise komponendid omavahel seostuvad (vt ka Howes et al., 2008; Salminen, 2014). Seega ei saa väita, et õpetajate tunnisuhtlusstiil määrab ópilaste keeleoskuste taseme.

\section{Piirangud ja järeldused}

Kui enamasti uuritakse õpetajate käitumist enesekohaste küsimustike abil või intervjueeritakse õpetajaid, siis praeguse uurimuse tarbeks vaadeldi õpetajate reaalset käitumist klassiruumis. Seejuures avaldusid mõned metoodilised piirangud. Esiteks, õppeprotsessi hindamisel vaadeldi ainult üht õpetaja ja õpilase vastastikmõju aspekti - õpetaja tunnisuhtlusstiili -, kaasamata teisi õppeprotsessi toetavaid tegevusi, nt mõistete ja nendevaheliste seoste kujundamist, õpilastele antava tagasiside kvaliteeti, tunni organiseerimist. Õpitõhusus sõltub eri tegurite koosmõjust, millega võib 
seletada osaliselt ka seose puudumist ópilaste emakeelealase akadeemilise edukuse ja õpetaja suhtlusstiili vahel. Teiseks ei analüüsitud õpetaja tunnisuhtlusstiili mõju laste individuaalsele eripärale (nt nõrgad $v s$. tugevad õpilased). Kolmandaks, praeguses uurimuses lähtuti õpetaja-lapse suhtluskoostöö analüüsimisel ainult õpetajast, kuid nähtust saab uurida ka lapse perspektiivist. Neljas piirang puudutab uurimuse usaldusväärsust - vaatlejate hinnangute kooskõla oli mõõdukas. Selle suurendamiseks tuleks pikendada uurijate vaatlustreeningut. Samuti hinnati ainult ühte emakeeletundi, mis peegeldab õpetaja isikupärast suhtlusstiili vaid ligilähedaselt. Objektiivsemat hinnangut võimaldaksid kordusmõõtmised.

Uurimuse tugevuseks on väga põhjalik õpetaja verbaalse ja mitteverbaalse suhtluse komponentide analüüs, uudsete uurimismeetodite kombineerimine, mitmetasandilised analüüsid ning õpetajate ja õpilaste esinduslik valim. Need võimaldavad teha sisukaid järeldusi ja anda soovitusi.

1. Klassiõpetajaid iseloomustasid üsna selgepiirilised suhtlusprofiilid. Õpilaste keeleoskuste arengu toetamisel on oluline, et õpetajad varieeriksid tunnisuhtlusstiili ning kohandaksid seda laste kognitiivse arengutaseme järgi, võimaldades õpilastel liikuda oma isiklikust arenguvallast kaugemale ja omandada uusi keeleoskusi (Võgotski, 2014).

2. Oluline on teadvustada ja kombineerida klassiruumis toimuvas õpidialoogis erinevaid suhtlusviise, et suurendada õppijatele vajaliku info tajumise kestust ja kvaliteeti.

3. Indiviidikesksete meetodite kombineerimine multimodaalse analüüsiga võimaldab uurimisel tuua selgemalt esile tegevused, millega õpetajad õppeprotsessis õpilast toetavad.

\section{Tänusõnad}

Uurimust on toetanud Eesti Teadusagentuur, grant nr IUT03-03 „Indiviidi akadeemiline ja isiksuslik areng formaalharidussüsteemis".

\section{Kasutatud kirjandus}

Alibali, M. W., \& Goldin-Meadow, S. (1993). Gesture-speech mismatch and mechanisms of learning: What the hands reveal about a child's state of mind. Cognitive Psychology, 25(4), 468-523. doi: http://dx.doi.org/10.1006/cogp.1993.1012

Allwood, J., \& Ahlsén, E. (2012). Multimodal communication. In A. Mehler, L. Romary, \& D. Gibbon (Eds.), Handbook of technical communication (pp. 435-460). Berlin, Boston, Beijing: De Gruyter Mouton.

doi: http://dx.doi.org/10.1515/9783110224948.435 
Bavelas, J. B., Chovil, N., Lawrie, D. A., \& Wade, A. (1992). Interactive gestures. Discourse Processes, 15(4), 469-489. doi: http://dx.doi.org/10.1080/01638539209544823

Bergman, L. R., Magnusson, D., \& El-Khouri, B. M. (2003). Studying individual development in an interindividual context: A person-oriented approach. Mahwah, London: Lawrence Erlbaum Associates.

Bergman, L. R., \& Wångby, M. (2014). Indiviidile suunatud käsitlusviis: lühike teoreetiline ja praktiline juhend. Eesti Haridusteaduste Ajakiri, 2(1), 7-28. doi: http://dx.doi.org/10.12697/eha.2014.2.1.02

Burchinal, M. R., Peisner-Feinberg, E., Pianta, R., \& Howes, C. (2002). Development of academic skills from preschool through second grade: Family and classroom predictors of developmental trajectories. Journal of School Psychology, 40(5), 415-436. doi: http://dx.doi.org/10.1016/S0022-4405(02)00107-3

Chomsky, N. (1964). The development of grammar in child language: Discussion. Monographs of the Society for Research in Child Development, 29(1), 35-42. doi: http://dx.doi.org/10.2307/1165753

Cohen, L., Manion, L., \& Morrison, K. (2007). Research methods in education (6th ed.). London, New York: Routledge.

Damhuis, R., \& de Blauw, A. (2008). High quality interaction in the classroom: A focus for professional learning. L1 Educational Studies in Language and Literature, 8(4), 107-126.

De Nooijer, J. A., van Gog, T., Paas, F., \& Zwaan, R. A. (2014). Words in action: Using gestures to improve verb learning in primary school children. Gesture, 14(1), 46-69. doi: http://dx.doi.org/10.1075/gest.14.1.03noo

Garcia, G. E., Pearson, P. D., Taylor, B. M., Bauer, E. B., \& Stahl, K. A. D. (2011). Socio-constructivist and political views on teachers' implementation of two types of reading comprehension approaches in low-income schools. Theory Into Practice, 50(2), 149-156. doi: http://dx.doi.org/10.1080/00405841.2011.558444

Gleason, J. B., \& Ratner, N. B. (2009). The development of language (7th ed.). Boston: Allyn \& Bacon.

Goodwin, C. (2000). Action and embodiment within situated human interaction. Journal of Pragmatics, 32(10), 1489-1522. doi: http://dx.doi.org/10.1016/S0378-2166(99)00096-X

Gosse, C. S., McGinty, A. S., Mashburn, A. J., Hoffman, L. M., \& Pianta, R. C. (2014). The role of relational and instructional classroom supports in the language development of at-risk preschoolers. Early Education and Development, 25(1), 110-133. doi: http://dx.doi.org/10.1080/10409289.2013.778567

Hamre, B. K., \& Pianta, R. C. (2010). Classroom environments and developmental processes: Conceptualization and measurement. In J. L. Meece \& J. S. Eccles (Eds.), Handbook of research on schools, schooling, and human development (pp. 25-41). New York, NY: Taylor \& Francis.

Howes, C., Burchinal, M., Pianta, R., Bryant, D., Early, D., Clifford, R., \& Barbarin, O. (2008). Ready to learn? Childen's pre-academic achievement in pre-kindergarten programs. Early Childhood Research Quarterly, 23(1), 27-50.

doi: http://dx.doi.org/10.1016/j.ecresq.2007.05.002 
Huttenlocher, J., Vasilyeva, M., Cymerman, E., \& Levine, S. (2002). Language input and child syntax. Cognitive Psychology, 45(3), 337-374.

doi: http://dx.doi.org/10.1016/S0010-0285(02)00500-5

Ingerpuu-Rümmel, E. (2012). Teadmise esiletulemine võõrkeeletunni multimodaalses suhtluses. Eesti ja soome-ugri keeleteaduse ajakiri ESUKA / Journal of Estonian and Finno-Ugric Linguistics JEF, 3, 9-30.

Karlep, K. (2005). Lev Võgotski ideede aktuaalsus tänapäeval. Haridus, 8, 30-35.

Kikas, E. (1997). Conceptual development in school-aged children: The impact of teaching (doctoral dissertation). Tartu Ülikool, Tartu. Retrieved from http://dspace.ut.ee/handle/10062/42695.

Krathwohl, D. R. (2002). A revision of Bloom's taxonomy: An overview. Theory into Practice, 41(4), 212-218. doi: http://dx.doi.org/10.1207/s15430421tip4104_2

Krips, H. (2011). Oppetajate suhtlemiskompetentsus ja suhtlemisoskused (doktoritöö). Tartu Ülikool, Tartu. Külastatud aadressil dspace.ut.ee/bitstream/handle/10062/17218/krips_heiki.pdf.

Krips, H. (2013). Õpetaja suhtlemiskompetentsusest ja selle arendamisest õpetajakoolituses. E. Krull, Ä. Leijen, M. Lepik, J. Mikk, L. Talts, \& T. Õun (toim.), Õpetajate professionaalne areng ja selle toetamine. Projekti „Õpetajate professionaalne areng ja selle toetamine” tulemused õpetajakoolituse teenistuses (1k 103117). Tartu: Eesti Ülikoolide Kirjastus.

LeBaron, C. (2008). Microethnography. In W. Donsbach (Ed.), The international encyclopedia of communication (Vol. 3, pp. 3120-3124). USA, Canada, etc.: Blackwell Publishing.

LoCasale-Crouch, J., Konold, T., Pianta, R., Howes, C., Burchinal, M., Bryant, M., ... Barbarin, O. (2007). Observed classroom quality profiles in state-funded prekindergarten programs and associations with teacher, program, and classroom characteristics. Early Childhood Research Quarterly, 22(1), 3-17.

doi: http://dx.doi.org/10.1016/j.ecresq.2006.05.001

Lyle, S. (2008). Dialogic teaching: Discussing theoretical contexts and reviewing evidence from classroom practice. Language and Education, 22(3), 222-240. doi: http://dx.doi.org/10.1080/09500780802152499

Margutti, P., \& Drew, P. (2014). Positive evaluation of student answers in classroom instruction. Language and Education, 28(5), 436-458. doi: http://dx.doi.org/10.1080/09500782.2014.898650

Mashburn, A. J., Pianta, R. C., Hamre, B. K., Downer, J. T., Barbarin, O. A., Bryant, D., ... Howes, C. (2008). Measures of classroom quality in prekindergarten and children's development of academic, language, and social skills. Child Development, 79(3), 732-749. doi: http://dx.doi.org/10.1111/j.1467-8624.2008.01154.x

McNeill, D. (1992). Hand and mind: What gestures reveal about thought. Chicago, IL: University of Chicago Press.

Mercer, N. (2013). The social brain, language, and goal-directed collective thinking: A social conception of cognition and its implications for understanding how we think, teach, and learn. Educational Psychologist, 48(3), 148-168. doi: http://dx.doi.org/10.1080/00461520.2013.804394

Mercer, N., \& Dawes, L. (2014). The study of talk between teachers and students, from the 1970s until the 2010s. Oxford Review of Education, 40(4), 430-445. doi: http://dx.doi.org/10.1080/03054985.2014.934087 
Merola, G., \& Poggi, I. (2003). Multimodality and gestures in the teacher's communication. Proceedings of the Gesture Workshop 2003, Genova, Italy. Retrieved from http://host.uniroma3.it/docenti/poggi/cursitopdf/poggiteacher.pdf.

Mihkels, K. (2013). Keel, keha ja kaardikepp: ópetaja algatatud parandussekventside multimodaalne analü̈̈s (doktoritöö). Tartu Ülikool, Tartu. Külastatud aadressil https://dspace.ut.ee/handle/10062/29189.

Mondada, L. (2006). Video recording as the preservation of fundamental features for analysis. In H. Knoblauch, J. Raab, H.-G. Soeffner, \& B. Schnettler (Eds.), Video analysis (pp. 51-68). Bern: Lang.

Nystrand, M., Wu, L. L., Gamoran, A., Zeiser, S., \& Long, D. A. (2003). Questions in time: Investigating the structure and dynamics of unfolding classroom discourse. Discourse Processes, 35(2), 135-198. doi: http://dx.doi.org/10.1207/S15326950DP3502_3

Orlich, D. C., Harder, R. J., Callahan, R. C., Trevisan, M. S., \& Brown, A. (2010). Teaching strategies: A guide to effective instruction (9th Ed.). Boston, MA: Wadsworth, Cengage Learning.

Pentimonti, J. M., \& Justice, L. M. (2010). Teachers' use of scaffolding strategies during read alouds in the preschool classroom. Early Childhood Education Journal, 37, 241-248. doi: http://dx.doi.org/10.1007/s10643-009-0348-6

Perry, K. E., Donohue, K. M., \& Weinstein, R. S. (2007). Teaching practices and the promotion of achievement and adjustment in first grade. Journal of School Psychology, 45(3), 269-292. doi: http://dx.doi.org/10.1016/j.jsp.2007.02.005

Pianta, R. C., \& Hamre, B. K. (2009). Conceptualization, measurement, and improvement of classroom processes: Standardized observation can leverage capacity. Educational Researcher, 38(2), 109-119. doi: http://dx.doi.org/10.3102/0013189X09332374

Pianta, R. C., La Paro, K. M., \& Hamre, B. K. (2008). Classroom assessment scoring system (CLASS). Baltimore: Paul H. Brookes.

Poggi, I. (2002). Towards the alphabet and the lexicon of gesture, gaze and touch. In P. Bouissac (Ed.), Multimodality of human communication: Theories, problems and applications. Virtual Symposium 2001-2002, University of Toronto, Victoria College, May 3-5, 2002.

Retrieved from http://www.semioticon.com/virtuals/talks/geyboui41.pdf.

Põhikooli riiklik õppekava (2010). Riigi Teataja I 2010, 6, 22. Külastatud aadressil https://www.riigiteataja.ee/akt/13273133.

Reznitskaya, A., Anderson, R. C., McNurlen, B., Nguyen-Jahiel, K., Archodidou, A., \& Kim, S. (2001). Influence of oral discussion on written argument. Discourse Processes, 32(2-3), 155-175. doi: http://dx.doi.org/10.1080/0163853X.2001.9651596

Salminen, J. (2014). The teacher as a source of educational support: Exploring teacher-child interactions and teachers' pedagogical practices in Finnish preschool classrooms. Jyväskylä: University of Jyväskylä.

Retrieved from http://urn.fi/URN:ISBN:978-951-39-5982-1.

Salminen, J., Hännikäinen, M., Poikonen, P.-L., \& Rasku-Puttonen, H. (2013). A descriptive case analysis of instructional teaching practices in Finnish preschool classrooms. Journal of Research in Childhood Education, 27(2), 127-152.

doi: http://dx.doi.org/10.1080/02568543.2013.767289 
Sime, D. (2008). „Because of her gesture, it's very easy to understand”: Learner's perceptions of teacher's gestures in the foreign language class. In S. G. McCafferty \& G. Stam (Eds.), Gesture: Second language acquisition and classroom research (pp. 259-290). New York, London: Routledge.

Stehman, S. V. (1997). Selecting and interpreting measures of thematic classification accuracy. Remote sensing of Environment, 62(1), 77-89. doi: http://dx.doi.org/10.1016/S0034-4257(97)00083-7

Zepeda, C. D., Richey, J. E., Ronevich, P., \& Nokes-Malach, T. J. (2015). Direct instruction of metacognition benefits adolescent science learning, transfer, and motivation: An in vivo study. Journal of Educational Psychology, 107(4), 954-970. doi: http://dx.doi.org/10.1037/edu0000022

Thompson, P. (2008). Learning through extended talk. Language and Education, 22(3), 241-256. doi: http://dx.doi.org/10.2167/le754.0

Toomela, A. (Ed.). (2010). Systemic person-oriented study of child development in early primary school. Frankfurt am Main etc.: Peter Lang.

Uibu, K., \& Männamaa, M. (2014). Õpetamistegevused ja õpilaste tekstimõistmine üleminekul esimesest kooliastmest teise astmesse. Eesti Haridusteaduste Ajakiri, 2(1), 96-131. doi: http://dx.doi.org/10.12697/eha.2014.2.1.05

Von Eye, A. (2000). Introduction to configural frequency analysis: The search for types and antitypes in cross-classifications. Cambridge: Cambridge University Press.

Võgotski, L. (2014). Mõtlemine ja kõne. Tartu: Ilmamaa.

Webb, N. M., Nemer, K. M, \& Ing, M. (2006). Small-group reflections: Parallels between teacher discourse and student behavior in peer-directed groups. Journal of the Learning Sciences, 15(1), 63-119.

doi: http://dx.doi.org/10.1207/s15327809jls1501_8

Wertsch, J. V. (1979). From social interaction to higher psychological processes: A clarification and application of Vygotsky's theory. Human Development, 22(1), 1-22. doi: http://dx.doi.org/10.1159/000272425 


\title{
Evaluation of primary school teachers' exemplar-based linguistic communication based on structured observation
}

\author{
Krista Uibu ${ }^{a 1}$, Marika Padrik ${ }^{a}$, Silvi Tenjes ${ }^{b}$ \\ ${ }^{a}$ Institute of Educational, University of Tartu \\ ${ }^{b}$ College of Foreign Languages and Cultures, University of Tartu
}

\section{Summary}

\section{Introduction}

Besides forming concepts and giving feedback, the exemplar-based linguistic communication is one of the effective ways to influence the learning process (Pianta \& Hamre, 2009; Salminen, 2014). Teachers use speech not only to convey information but also to communicate, as well as to control and mediate cognitive actions (Mercer, 2013; Vygotski, 2014). The learning process is multi-modal i.e. the verbal interaction between a teacher and a pupil is supported by non-verbal communication, such as gestures and prosody (Mercer, 2013). Studies, conducted during the last decades, have shown that dialogue that directs thinking and facilitates discussion, the feedback that models studying, and the teacher's language use that is appropriate to the level of development of a pupil, have a positive effect on the development of students' speech comprehension, as well as academic achievement in general (see Gosse et al., 2014; Mashburn et al., 2008; Salminen, 2014). Teachers support the development of comprehensive learning, meta-cognition and self-reflection skills by the deliberate choice of questions in dialogues, by repeating and re-phrasing the pupils' answers as well as explaining the meaning of words and connecting them with previous knowledge (Nystrand et al., 2003; Pianta \& Hamre, 2009).

There is a common consent among researchers that teachers should be able to analyse their own use of language and communication skills in the classroom environment. However, the potential of the exemplar-based linguistic communication is not sufficiently applied, and in teachers' training too little attention is paid to the methods to improve it (Lyle, 2008; Mercer \& Dawes, 2014; Pentimonti \& Justice, 2010). No studies have been carried out in Estonia to find out how teachers shape the discourse in a classroom

1 Institute of Education, University of Tartu, Salme 1a, 50103 Tartu, Estonia; krista.uibu@ut.ee 
by their use of language and non-verbal communication, and what influence it has on the development of their pupils.

The aim of this study was to evaluate the exemplar-based linguistic communication of Estonian primary school teachers in Estonian language lessons, and to ascertain what influence it had on their pupils' language proficiency. The following hypotheses were formulated for the research:

1. We assumed that teachers use different verbal communication means in different proportions (Mercer \& Dawes, 2014; Salminen, 2014).

2. We supposed that Estonian teachers use a limited amount of conversation in their classroom and the questions to support conversation are random. Teachers pay little attention to the meanings of words, and do not use language to comment on their own, and pupils' actions.

3. We assumed that teachers with different linguistic communication profiles differ from each other also by the use of non-verbal communication means. We expected that the group of teachers who use a wider range of verbal communication means, use more actively different non-verbal communication means.

4. On the basis of previous studies, we assumed that pupils achieve better results under teachers who involve them more in the learning dialogue, and use different communication means in a flexible manner.

\section{Method}

The study evaluated teachers' exemplar-based linguistic communication used by 46 Estonian primary school teachers in the Estonian language lessons and analysed its influence on pupils' $(N=611)$ linguistic achievement in Grade 3. A measuring system for structured observation, the Classroom Assessment Scoring System (CLASS; Pianta et al., 2008), was used to evaluate the teachers' verbal communication. This measuring system allows the evaluation of the following verbal communication means on five scales: 1) Conversational frequency, 2) The choice of questions, 3) Repeating and completing pupils answers, 4) Commenting actions, 5) The level of complexity in the use of language.

The native language proficiency of pupils was measured by a Native language test in Grade 3. The test measured students' text comprehension and vocabulary skills, basic knowledge of spelling and grammar rules, knowledge of word classes and a basic knowledge of syntax. The general score of the Estonian language test was calculated on the basis of the right answers given by pupils. Both variable- and person-oriented approaches to the data 
analyses were used (Bergman et al., 2003; Cohen et al., 2007). The nonverbal modalities of teachers were analysed by the method of multi-modal video analysis (Goodwin, 2000; Mondada, 2006).

\section{Major results and discussion}

In line with the assumption that teachers do not comment on their own, or pupils' actions in a classroom, it appeared that teachers expressed their thoughts audibly, or added explanatory comments to their own or pupils' actions substantially less than used by other options of verbal communication means. The conversational frequency and the level of complexity of language use by primary school teachers was rated as average i.e. the teachers talked regularly to pupils but the conversations were typically limited to one or two turn-taking. The initiative of pupils was not always taken into account (Pianta et al., 2008). As to the choice of questions, the closed-ended ones dominated and they were mainly used to check on how much the pupils knew (cf. Mercer \& Dawes, 2014). However, teachers explained the meaning of new words to pupils relatively randomly. Howes et al. (2008) have argued that the ability of a teacher to formulate concepts is the most important pre-condition for academic achievement, while giving feedback does not seem to have the same influence.

For analysing teachers' habitual classroom communication styles, four communication profile groups were identified. The teachers belonging to the group of Average variety were characterised by the steadily uniform use of all components. The teachers with high level language use (High variety) were characterised by a flexible and varied use of different communication means that helps pupils learn comprehension, awareness of their own thinking process, and learn to argue (vt Pianta et al., 2008; Salminen, 2014). In the classes of these teachers, dialogue was often used and encouraged by regularly asking open ended questions. A quarter of teachers were very lowly rated in all components (Low variety). They were characterised by asking closed ended questions that presumed short answers, and were asked mainly to check the pupils' knowledge. These teachers did not comment on their actions and were not aware of the influence of their language use as a means of support to the learning process. Earlier studies on teacher-pupil interaction have revealed that teachers do not support pupils evenly in all observed areas (see Howes et al., 2008). It can be assumed that due to the strong connections between verbal communication means, the level of teachers within the profiles was quite homogeneous. Besides, the 
Mixed profile ( $16 \%$ of teachers) was detected that it consisted of teachers whose verbal communication was either average or at a higher level in different components. These teachers stood out because of the lower level choice of questions and linguistic complexity of their language use, but as to other components they were given the highest ratings.

The analysis of non-verbal communication of the teachers belonging to the above-mentioned profile groups revealed that the non-verbal components carried out by teachers of four profile groups varied by the intensity of certain type of gestures and prosodic means used by teachers. The study confirmed the assumption that the teachers who used verbal communication means more diversely and in a more flexible manner were also more active in non-verbal communication.

Then we analysed how much the pupils of teachers with different communication profiles differ in their level of the Estonian language proficiency. The number of pupils with high language proficiency was bigger in the groups of teachers who did not use different communicative components that frequently (Low variety). Teachers with this profile also had fewer pupils getting lower results in the Estonian language test than expected. It may be because children's linguistic capabilities do not depend only on the action of teachers but also in the genetics, environment and other factors (Huttenlocher et al., 2002; Vygotski, 2014). Opposite results appeared in the teachers' profile group High variety, which included more children with low language proficiency than expected. The high level language use of a teacher does not compensate for the inadequacy of teaching material and curriculum with the level of weak pupils. Although, it has been found that teacher's activities that support the learning process influence pupils' development more directly than, for example, the organisation of studies (Mashburn et al., 2008; Pianta et al., 2008). Thus, the teacher's high level of communication skills does not guarantee higher study results in native language proficiency (Salminen, 2014).

It also appeared that within the group where teachers varied the communication means at the average or higher level (Mixed profile), the number of pupils that passed the native language test very well, was smaller than expected. It should be remembered that a teacher's communication style is only one of the ways to support the learning process (Pianta et al., 2008). It is possible that the method a teacher uses to organise learning activities and gives instructions to pupils, may be more important than the teachers' exemplar-based linguistic communication (Howes et al., 2008; Salminen, 2014). 


\section{Acknowledgements}

This work was supported by the Estonian Research Council Grant No IUT03-03 (Academic and personal development of an individual in the system of formal education).

Keywords: classroom communication style, communicative profile, primary school teacher, structured observation 